\title{
GEOLOGIA DA REGIÃO DE POUSO ALEGRE-MACHADO: ANÁLISE GEOMÉTRICA DE DOBRAMENTOS SUPERPOSTOS
}

\author{
ALBERTO PIO FIORI *, PAULO MILTON BARBOSA LANDIM ** e JORGE SILVA BETTENCOURT ***
}

\begin{abstract}
The present paper is a result of geological mapping of an area of about $3000 \mathrm{~km}^{2}$ situated in the South of Minas Gerais. Geologically the area is underlain by the Pinhal Group, Amparo Group and the Silvianópolis Complex of Brasiliano, Trans-Amazonic and Archaean ages respectively.

On the basis of structural analysis the effects of superposed folding in the area assignable to four phases of deformation were identified. The oldest of these is designated $F n$ followed by $F n+1$, $F n+2$ and $F n+3$.

The $F n$ phase represents the culmination of a pre-Trans-Amazonic event involving migmatization and formation of granulites and is recognisable solely in the rocks of the Silvianópolis Complex. The $F n+1$ phase characterized by isoclinal folding, which affected both the Amparo Group and the Silvianópolis Complex, took place in the Trans-Amazonic orogeny. The subsequent $F n+2$ phase caused isoclinal folding of the $F n+1$ folds with fold axes and axial planes in a north-westerly direction and vergence to the northeast. Crescent shaped interference figures of type 2 were formed in this phase as a result of interference consequent on the refolding of the $F n+1$ folds. This phase is provisionally correlated with the Uruaçuano Cycle.

Finally, the $F n+3$ folding affected the $F n+1$ and $F n+2$ structures resulting in flexural or open folds with northeast fold axes and axial surfaces without any definable vergence. Type 3 interference lïgures originated by the superposition of the $F n+3$ on $F n+1$ folds and are characterized by approximate coaxial refolding. The $F n+3$ deformation is tentatively related to the Brasiliano Cycle.
\end{abstract}

GEOLOGIA REgIONAL Generalidades O modelo geológico da área foi concebido por Ebert em várias publicações iniciadas na década de 50. Em 1956, considerou os Grupos Paraíba, Andrelândia e São João del-Rei unidades estratigráficas cronologicamente equivalentes, integrantes de um cinturão orogênico do Pré-Cambriano Superior, amoldado em torno do Cráton do São Francisco. O Grupo São João del-Rei é arquimetamórfico ou epizonal e equivalente ao Grupo Bambuí; o Grupo Andrelândia é mesozonal, correspondente ao externídeos do cinturão geossinclinal; enquanto o Grupo Paraiba é catazonal, correspondendo aos externídeos desse cinturão. Os diversos grupos refletem ainda, segundo o autor, diferentes ambientes de deposição: o Grupo São João del-Rei caracterizado por sedimentos clásticos finos e calcários; o Andrelândia, representando condições de transição eu- para miogeossinclinais; e o Paraiba de sedimentação eu-geossinclinal.

Ainda segundo o citado autor, ao sul de Belo Horizonte, na altura do paralelo $22^{\circ} \mathrm{S}$, o cinturão sofre uma bifurcação. Um ramo passa a infletir para noroeste, contornando o Cráton tendo sido dominado de Araxaídes, o qual, passando por Três Coraçð̃es e Varginhas, penetra no Estado de Goiás; o outro, constituindo os Paraibides, penetra no Estado de São Paulo, nas proximidades de Lindóia e Itapira, estendendo-se até os Estados de Paraná e Santa Catarina.
Delimitada pelos Araxaídes, Paraibides e pela sinéclise do Paraná, ocorre uma área triangular denominada Maciço de Guaxupé (Almeida et al., 1976). A caracterização do Maciço de Guaxupé é devida a Ebert (1956), que o considerou como um bloco de embasamento mais antigo delimitado pelas faixas de dobramento Paraibides e Araxaídes. Essas faixas foram consideradas como pertencentes ao Pré-Cambriano Superior, tendo a primeira direçðes estruturais nordeste enquanto a segunda, noroeste. Em 1968, o mesmo autor refere-se ao fato de as estruturas dos Araxaídes e Paraibides cruzarem-se mutuamente em profundidade, na área entre Campinas (SP) e Pouso Alegre (MG). Oliveira (1973) e Oliveira e Alves (1974) verificaram que as estruturas dos Araxaídes, com direçoes noroeste, apresentam estruturas nordeste superimpostas na região de Caconde-São José do Rio Pardo.

A respeito ainda do Maciço de Guaxupé, Ebert (1968) apresentou outra versão, tendo-o reinterpretado, ao contrário do que fizera em 1956, como representado a "zona central" granítica-migmatítica dos Araxaídes e, portanto, cronologicamente equivalentes. No mapa geológico do Brasil (1971), o Maciço de Guaxupé é tido como formado por granitóides referiveis ao PréCambriano indiviso circundado por metassedimentos com idades entre 900 e 1300 m.a. (Grupos Araxá e Andrelândia). No mapa tectônico do Brasil (1971), o

\footnotetext{
* Departamento de Mineralogia e Recursos Minerais, l.G.C.E., UNESP, Campus de Rio Claro - Rio Claro (SP)

** Departamento de Geologia Geral e Aplicada, I.G.C.E., UNESP, Campus de Rio Claro - Rio Claro (SP)

*** Industrias Votorantim S.A. - São Paulo (SP)
} 
Maciço é apresentado como constituído por granitóides sintectônicos brasilianos envolvidos por rochas mais antigas, rejuvenescidas no Ciclo Brasiliano. Fyfe e Leonardos Jr. (1974) voltaram à concepção de que o maciço é uma unidade composta por rochas mais antigas com idades transamazônicas e circundado por cinturões entre 1400 e 600 m.a. (cinturões Brasilia e São Roque). Para Almeida et al. (1976), o Maciço de Guaxupé, cuja idade não é especificada, é constituído por granulitos migmatizados e cortados por rochas granitóides e delimitado pelos grupos Andrelândia e Itapira, de idade uruaçuana. Wernick (1978a) considerou o Maciço de Guaxupé como um bloco crustal de idade essencialmen. te transamazônica, possivelmente com núcleos arqueanos mais ou menos intensamente afetados durante o Pré-Cambriano Superior. Inclui no Maciço os grupos Amparo e Pinhal além das formações Eleutério e Pouso Alegre. Como limite sudeste do Maciço, propðe as falhas de Jundiuvira e Itu.

Coube ainda a Ebert $(1968,1971$ e 1974) a correlação entre as unidades criadas e estudadas em Minas Gerais e as posteriormente caracterizadas no Estado de São Paulo. Assim, correlacionou tentativamente o Grupo Barbacena com o Grupo Amparo e o Grupo Andrelândia com o Grupo Itapira.

No entanto, com a execução de novos mapeamentos e investigaçð̃es geocronológicas, o modelo de Ebert sofreu algumas modificaçðes. Assim, Cordani et al. (1973) encontraram vestígios indicativos de superposiçðes de três ciclos orogênicos nos Estados de Minas Gerais e Rio de Janeiro. O Grupo Barbacena teria a idade de 2800 m.a.; o Grupo Paraíba, 2000 m.a.; e os granitos e migmatitos da Serra dos Órgãos, 620 m.a. Estes últimos são correlativos do Grupo Pinhal (Wernick, 1978b). Wernick et al. (1976) mostraram que o Grupo Amparo pertence realmente ao Ciclo Transamazônico, não sendo possível sua correlação com o Grupo Barbacena. Estudos de Pires et al. (1970) demonstraram a impossibilidade de enquadrar os gQ̣nditos da região de Pouso Alegre no Grupo Barbacena; e Wernick e Penalva (1973) ressaltaram de modo idêntico não ser possivel, na região de Itapira, distinguir o Grupo Amparo do Itapira, considerando em consequência ambas as unidades equivalentes.

Os trabalhos de mapeamento dos projetos Caldas I (1974), Caldas II (1975) e Ouro Fino (1976), desenvolvidos na área considerada por Ebert (1968) como de ocorrência do Grupo Andrelândia, revelaram que as rochas ali presentes eram perfeitamente correlacionáveis às litologias do Grupo Amparo, como caracterizou Wernick (1967) para a região de Amparo. Na continuação do mapeamento no Projeto Pouso Alegre (1977), o Grupo Amparo pode ser estendido até a altura de Poço Fundo. Dessa forma, a faixa de metassedimentos situada entre os maciços de Pinhal e Socorro, sobre a qual estão situadas as cidades de Ouro Fino e Pouso Alegre, é representativa do Grupo Amparo, não existindo a interdigitação desse Grupo com o Andrelândia conforme se refere Ebert (1968).

Choudhuri et al. (1978) descreveram-se a oeste e sudoeste de Silvianópolis estruturas migmatíticas que podem representar migmatitos antigos referíveis ao embasamento do Grupo Amparo. Choudhuri, Fiori e Bettencourt (1978) consideraram os charnockitos ocorrentes na região de Machado como rochas provavelmente mais antigas que o Grupo Amparo, inclusos nos migmatitos do embasamento do citado grupo. Referem-se, ainda, a pelo menos três eventos metamórficos nessas rochas. Fiori, Wernick e Bettencourt (1978) caracterizaram uma evolução policíclica para a área referindo a fácies de deformação dos ciclos Transamazônico, Uruaçuano e Brasiliano, cujas direções estruturais principais são, respectivamente, ENE-EW; NS-NW e NNE-NE. Naquela oportunidade, caracterizam figuras de interferência originadas pela superposição das diversas fases de dobramento. Fiori (1979a e $b$ ), baseado em estudos estruturais, identifica um núcleo arqueano na área, definindo-o como Complexo de Silvianópolis. Choudhuri, Fiori e Bettencourt (1978), e Fiori e Choudhuri (1979) analisaram as fases de migmatização e dobramentos superpostos nos granulitos de Machado.

Caracterização das unidades mapeadas Examinando-se o mapa geológico-estrutural (Fig. 1), nota-se que três unidades maiores se destacam:

$A$ - Um conjunto de rochas, referíveis ao Grupo Pinhal, caracterizado por migmatitos de injeção de idade brasiliana.

$B$ - Um conjunto heterogêneo de rochas metamórficas dobradas, de natureza predominantemente metassedimentar, de idade transamazônica, referíveis ao Grupo Amparo.

$C$ - Um conjunto de rochas relacionáveis ao Complexo de Silvianópolis caracterizado por migmatitos do tipo gerados in situ, granulitos e gnaisses graníticos, de idade provavelmente arqueana.

Além dessas unidades, que perfazem cerca de $90 \%$ do total da área estudada, ocorre a Formação Pouso Alegre representada por uma pequena mancha isolada, perfazendo alguns quilometros quadrados de metassedimentos de baixo grau, principalmente metassiltitos e metarenitos.

\section{GEOLOGIA ESTRUTURAL Principais estruturas} mapeadas $\mathrm{Na}$ parte sul da área, os traços axiais do principal sistema de dobramento têm direção dominante nordeste, caracterizando-se por dobras abertas com superfícies axiais verticais; na parte norte, o principal sistema de dobramento apresenta traços axiais de direção noroeste, caracterizando-se por dobras isoclinais, com nítida vergência para nordeste. Esses dois sistemas de dobramento afetam um dobramento mais antigo, isoclinal, com intensa transposição plano-axial gerando um falso acamamento nas litologias do Grupo Amparo e uma gnaissificação por transposição de estruturas migmatíticas no Complexo de Silvianópolis. Nesta primeira fase de dobramento, o Complexo de Silvianópolis e o Grupo Amparo tornaram-se estruturalmente concordantes pela foliação de transposição.

A intersecção dessas diversas fases de dobramento deu origem a estruturas de interferência de redobramento, sendo as principais estruturas denominadas Santo Antônio, Silvianópolis e da Cachoeira, representando o tipo 3 (Ramsay, 1962 e 1967); e as estruturas de Serra nia, Machado, Carvalhópolis e Grão-Mogol, representando o tipo 2. (Para maiores detalhes, ver Fiori, 1979.) 
As principais zonas de falhas identificadas na área são as de Jacutinga e Bueno Brandão-Borda da Mata, na parte sul da área de caráter eminentemente transcorrente, enquanto a zona de falha de São João da Mata, bordejando o Maciço de Pinhal, é de caráter de empurrão, tendo-se medido valores de até $15^{\circ}$ de inclinação do plano de cizalhamento. De natureza duvidosa é a falha de Espírito Santo do Dourado, havendo evidência de se tratar também de falha de empurrão.

\section{FASES DE DEFORMAÇAO}

Fase de deformação Fn Esta fase é a mais antiga identificada na área estudada, tendo sido verificada no complexo migmatítico-gnáissico de Silvianópolis, considerado como parte do embasamento do Grupo Amparo. Nem sempre esta fase é facilmente identificada devido à reestruturação imposta pelas fases de deformação subseqüentes. No entanto, em certos afloramentos, pode ser reconhecida por um bandeamento resultante de uma migmatização in situ. $\mathrm{O}$ bandeamento é caracterizado por bandas claras compostas por quartzo e feldspato, e intercaladas com bandas escuras compostas por hornblenda e biotita, principalmente. São bandas com formas irregulares, variando bruscamente em espessura e não apresentando uma continuidade muito grande. As bandas claras e escuras são concordantes na maioria dos casos.

$\mathrm{Na}$ quase totalidade dos afloramentos, a antiga estrutura migmatítica é transformada em gnaissificação em fase $F n+1$, com alternância de veios milimétricos claros e escuros, dispostos paralelamente ou subparalelamente. Ainda assim o antigo bandeamento é possível de ser identificado por um exame cuidadoso da rocha. Dobras intrafoliares disruptas, estruturas sigmoidais e camadas de paleossoma disruptas ou em forma de boudins são remanescentes indicativos desse bandeamento possível de ser identificados à escala de afloramento.

Fase de deformação Fn +1 Esta fase é bem desenvolvida nos metassedimentos (e migmatitos) do Grupo Amparo, sendo a mais antiga fase de deformação identificada nessas rochas. E caracterizada por uma foliação de transposição paralela ao antigo acamamento, desenvolvida por uma fase de dobramento isoclinal. Esta foliação foi também identificada nas rochas pertencentes ao Complexo de Silvianópolis e recebeu a designação de foliação $S T$. As primeiras características da fase de deformação $F n+1$ são as seguintes:

\section{As dobras $F n+1$}

As dobras $F n+1$, identificadas em afloramentos do Grupo Amparo, são dobras isoclinais com forte espessamento nos ápices e forte adelgaçamento nos flancos, até sua ruptura. Neste último caso, originam-se dobras intrafoliares disruptas.

A superfície axial dessas dobras não apresenta uma inclinação definida, tendo-se visto dobras $F n+1$ com a superfície axial variando de horizontal a vertical devido ao redobramento a que foram submetidas. São dobras desenhadas pelo antigo acamamento sedimentar possível ainda de ser identificado pela alternância de camadas de composição, granulometria, espessura e cores diferentes. Apresentam, via de regra, o ápice crenulado. Seus flancos são sempre paralelos à superfície axial, materializada na forma de foliação.

As dobras $F n+1$ não são facilmente encontradas nos afloramentos, devendo-se raspá-los cuidadosamente de forma a cortar perpendicular ou transversalmente a gnaissificação. Variam bastante em tamanho, indo de milimétricas a dobras com vários quilômetros de extensão ao longo do traço axial. Seus traços axiais variam bastante de direção, conforme se pode ver no mapa geológico-estrutural anexo. Na parte sul da área, há direçðes variando entre $\mathrm{N} 70 \mathrm{E} \cdot \mathrm{e} \mathrm{E}-\mathrm{W}$, enquanto na parte norte em torno de $\mathrm{N} \mathrm{50/60} \mathrm{W} \mathrm{devido} \mathrm{ao} \mathrm{redobramento}$ a que foram submetidos na fase $F n+2$.

\section{A Foliação $S T$ no Grupo Amparo}

Desenvolvida plano-axialmente nas dobras $F n+1$, ocorre uma foliação de transposição muito intensa denominada $S T$. A foliação $S T$ pode ser reconhecida nos metassedimentos do Grupo Amparo por crenulaçðes nos ápices de dobras $F n+1$, ruptura de flancos e espessamento de ápices de dobras $F n+1$; esmagamento de grãos minerais nos planos de foliação e por dobras in. trafoliares disruptas (rootless fold). É sistematicamente paralela ao antigo acamamento, podendo ser identificada nos afloramentos como uma clivagem de acamamento (bedding cleavage).

\section{A foliação $S T$ no Complexo de Silvianópolis}

A foliação de transposição $S T$ nos migmatitos do Complexo de Silvianópolis tem um efeito de homogeneização ao transformar as estruturas migmatíticas em gnaissificação, com níveis claros e escuros, dispostos paralelamente ou subparalelamente, de espessura milimétrica bastante regular. Ressalte-se que esses niveis nunca são contínuos. A foliação $S T$ pode ser identificada nessas rochas por dobras isoclinais disruptas, com superfícies axiais paralelas à foliação $S T$; estruturas sigmoidais, camadas disruptas e em forma de boudins; e intenso esmagamento de minerais nos planos de foliação e crenulaçðes nos ápices das dobras intrafoliares.

As dobras intrafoliares são identificadas mais facilmente em pequenos níveis de paleossoma ricos em máfi$c o s$, podendo também ser identificadas em níveis mais claros de neossoma. Neste último caso, via de regra, as dobras são centimétricas ou milimétricas e são mais abundantes que as primeiras.

Fase de deformação $\mathrm{Fn}+2$ Esta fase atinge seu máximo de intensidade na parte norte da área, sendo a responsável pela reorientação da gnaissificação originada na fase anterior de N 60/90 E para NW. As dobras $F n+2$ variam em perfil, de isoclinais a dobras abertas, com planos axiais inclinados para sudoeste com valores em torno de $50^{\circ}$ a $60^{\circ}$ e o eixo com direção em torno de $\mathrm{N} 50 \mathrm{~W}$. Variam em tamanho de centimétricas a vários quilômetros de comprimento, medido ao longo de seu traço axial. No campo, são facilmente identificáveis, pois dobram o antigo acamamento sedimentar e a fo- 
liação $S T$. Como característica adicional apresentam o ápice antiformal mais fechado que o ápice sinformal, caracterizando-se o último como uma curva suave, lembrando a letra $U$, e o primeiro, a letra $V$ invertida. Geralmente não apresentam foliação desenvolvida paralela à superfície axial nos ápices das dobras a nível de amostra de mão. Em certos locais, no entanto, principalmente nos termos litologicos mais competentes, existem indicações de que uma foliação $F n+2$ foi desenvolvida, porém sua ocorrência não é generalizada pela área.

Fase de deformação $\mathrm{Fn}+3$ Esta fase desenvolve-se principalmente na parte sul da área, onde dá origem a dobras cujos traços axiais têm comprimento de vários quilômetros, em direções variáveis entre $40^{\circ}$ e $60^{\circ}$ nordeste. A atitude de seus planos axiais, calculados a partir de dados de foliação, tem valores de N 55-60 E/75-77 SE ou NW, não caracterizando assim vergência definida. São dobras concêntricas dobrando suavemente a foliação ST paralela ao acamamento. São mais facilmente identificadas em escala regional que em escala de afloramento. Característica dessas dobras é o duplo sentido de caimento do eixo, verificado em escala regional, o que dá origem a estruturas branquissinformais e branquiantiformais, cujo eixo maior é orientado paralelamente ao traço axial $F n+3$. Não apresentam foliação plano-axial.

\begin{abstract}
ANÁLISE ESTRUTURAL
Procedimentos de campo e tratamento dos dados Os dados estruturais re sultantes do mapeamento da área em questão evidenciam padrões de deformação muito complicados resultantes de deformaçoes superpostas que afetaram as rochas da área. Devido à heterogeneidade das deformações observadas, o critério usado para o inventário dos parâmetros estruturais baseou-se não só nas diferenças estruturais e feições litológicas observadas como também na compartimentação em blocos resultantes de falhamentos.
\end{abstract}

Assim, o mapa geológico-estrutural da área foi dividido em diversas subáreas com a finalidade de se fazer uma análise detalhada das diferentes fases de deformação. Para cada subárea foram elaborados diagramas estruturais.

A Fig. 2 mostra a distribuição das diferentes subáreas. Estas foram delimitadas tendo-se em conta principalmente as áreas de domínio dos grupos Amparo e Pinhal, e do Complexo de Silvianópolis. Assim, as subáreas de números $1,2,2-A, 3-B, 3-C, 4-C, 3-D$, 3-E, $I H$ e 2-I referem-se ao Complexo de Silvianópolis; as de números $2-B, 2-C, 2-D, 2-E, 1-G, 3-H, 4-I, 1-I$, $2-F, 2-G, 2-H$ e $3-I$ ao Grupo Amparo; e as de números $1-A, 1-B, 1-C, 1-D, 1 \sim E$ e $1-F$ ao Grupo Pinhal. Seus limites naturais são os contatos traçados entre essas unidades, exceção feita à parte sul da área, onde as subáreas $2-F, 2-G, 2-H$ e 3- $I$ têm seus limites determinados pelas falhas de Bueno Brandão-Borda da Mata e de Jacutinga. No caso das áreas $3-I$ e $2-H$, o limite sul é feito com a subárea 2- $I$ interposta entre essas subáreas e a falha de Bueno Brandão-Borda da Mata.

Tal subdivisão, segundo as diferentes unidades litoestruturais, justifica-se pelo fato de que, para cada unidade, a deformação final, resultante do somatório das deformações superimpostas, apresenta um resultado homogêneo enquanto em unidades diferentes o resultado pode ser heterogêneo, pois podem apresentar mais e menos fases superimpostas. No caso da divisão na parte sul da área, usando-se como limites naturais de subáreas as falhas de Jacutinga e Bueno Brandão-Borda da Mata, encontra justificativa no fato de se procurar evitarem erros introduzidos devido a um possível basculamento e/ou rotação de blocos ao longo dessas duas grandes falhas transcorrentes.

Aproximadamente 1600 medidas estruturais foram obtidas nas quadrículas mapeadas, sendo esses valores tratados estatisticamente de maneira a permitir uma análise adequada do padrão tectônico da área. $O$ inventário dos parâmetros estruturais foi feito sistematicamente, quando possível, em todos os afloramentos, dando-se ênfase especial à foliação (gnaissificação e foliação de transposição) e acamamento (nos metassedimentos), superfícies axiais e eixos de dobras. Os pólos dos elementos planares e lineares foram lançados em diagramas de igual área (Schmidt-Lambert). A avaliação estatística dos dados foi feita por método gráfico, sendo os diagramas de contorno no hemisfério inferior obtidos a partir do Diagrama de Vistelius.

Os valores de foliação revelam-se muito variáveis na área. Os planos de acamamento são de difícil observação à exceção do Grupo Amparo, onde são freqüentes intercalações de camadas de quartzitos, anfibólitos e micaxistos. Além disso, os gnaisses do Grupo Amparo apresentam uma grande variedade de tipos diferentes, tais como gnaisses ocelares, leucognaisses, hornblenda gnaisses etc., que ressaltam o antigo acamamento sedimentar. No Complexo de Silvianópolis, o acamamento não pôde ser identificado.

\section{ESTRUTURAS LOCAIS: FOLIAÇÃO E EIXOS DE DOBRAS}

A análise dos diagramas de contornos presentes na Fig. 3 e Tab. 1 mostra a concentração de pólos, em três máximos distintos, indicativos de diferentes orientações da foliação. Na Tab. 2, os diferentes máximos bem como seus respectivos diagramas estão representados.

Assim, o máximo I mostra a orientação da foliação entre $\mathrm{N}$ 30-40 W, tanto para rochas do Complexo de Silvianópolis como para as rochas do Grupo Amparo. Em alguns casos é possível determinar estatisticamente o eixo das dobras, obtendo-se valores variáveis entre $\mathrm{N} 70-30 \mathrm{~W}$, com caimentos para noroeste, com valores entre $0^{\circ}$ e $20^{\circ}$ (diagramas 1,2 e 2-C). O máximo II mostra a orientação da foliação entre $\mathrm{N}$ 60-80 E tanto para as rochas do Complexo de Silvianópolis como para as do Grupo Amparo. Na maioria dos casos, pode-se determinar a altitude do eixo $\beta$ de dobras concêntricas da foliação, como os casos dos 1-F, 2-F, 1-G, 2- $G, 1-H, 2-H$, 1- $I$ e $2 \sim I$, pois permitem traçar um plano que contêm estatisticamente todos os pólos das foliaçōes lançadas nesses diagramas. Assim sendo, o eixo $\beta$ iapresenta valores variáveis entre $\mathrm{N} 60 \mathrm{E}$ e E-W, com caimentos ora para nordeste, ora para sudoeste, com valores menores que $30^{\circ}$. O máximo III apresenta valores de foliação entre N 30-45 E tanto para rochas do Complexo de Silvianópolis como para as rochas do Grupo Amparo. 


\begin{tabular}{|c|c|c|c|}
\hline 1 & 80 pólos. Foliação. & Contornos: & $1,2-4,8-12,0-14,4 \%$ \\
\hline 2 & 150 pólos. Foliação. & Contornos: & $0,66-4,62-6,6-8,58-10,56-13,2 \%$ \\
\hline $1-A$ & 29 pólos. Foliação. & Contornos: & $6,0-8,0-10 \%$ \\
\hline $2-A$ & 17 pólos. Foliação. & Contornos: & $5,8-10 \%$ \\
\hline $3-A$ & 59 pólos. Foliação. & Contornos: & $1,69-3,0-6,0-9,0-12 \%$ \\
\hline $1-B$ & 19 pólos. Foliação. & Contornos: & $5-10-15-20-25 \%$ \\
\hline $2-B$ & 18.pólos. Foliação. & Contornos: & $5-15-20-25 \%$ \\
\hline $3-B$ & 10 pólos. Foliação. & Contornos: & $10-20 \%$ \\
\hline $1-C$ & 10 pólos. Foliação. & Contornos: & $5-10 \%$ \\
\hline $2-C$ & 46 pólos. Foliação. & Contornos: & $2-6-10-14 \%$ \\
\hline $3-C$ & 23 pólos. Foliação. & Contornos: & $6,5-13-19 \%$ \\
\hline $4-C$ & 16 pólos. Foliação. & Contornos: & $16-33 \%$ \\
\hline $2-C^{\prime}$ & 15 eixos de dobras. & Contornos: & $6-13 \%$ \\
\hline $1-C^{\prime}$ & 6 eixos de dobras. & Contornos: & $16-32-48 \%$ \\
\hline $3-D$ & 48 pólos. Foliação. & Contornos: & $5-10-15 \%$ \\
\hline $2 \sim D$ & 20 pólos. Foliação. & Contornos: & $5-10-15-20 \%$ \\
\hline $1-D$ & 22 pólos. Foliação. & Contornos: & $5,4-9,0-14,0-18,0 \%$ \\
\hline $3-E$ & 60 pólos. Foliação. & Contornos: & $1,6-3,3-4,9-6,5 \%$ \\
\hline 2- $E$ & 62 pólos. Foliação. & Contornos: & $13,2-17,6-22,0-26,4 \%$ \\
\hline $1-E$ & 17 pólos. Foliação. & Contornos: & $5,8-11,6-17,4 \%$ \\
\hline $1-E^{I}$ & 10 eixos de dobras. & Contornos: & $10-20-30 \%$ \\
\hline $1-F$ & 28 pólos. Foliação. & Contornos: & $3,5-7,0-10,5-14,0-17,5 \%$ \\
\hline $2-F$ & 184 pólos. Foliação. & Contornos: & $1-2-4-6-8 \%$ \\
\hline $2-F^{\prime}$ & 22 pólos plano axiais. & Contornos: & $4,5-9,0-13,5-18 \%$ \\
\hline $2-F^{2}$ & 36 eixos de dobras. & Contornos: & $3-5,5-11-16,50 \%$ \\
\hline $1-G$ & 20 pólos. Foliação. & Contornos: & $2-5-10-15 \%$ \\
\hline $2-G$ & 25 pólos. Foliação. & Contornos: & $4-9-12-15 \%$ \\
\hline $1-G^{\prime}$ & 15 eixos de dobras. & Contornos: & $15-25-30 \%$ \\
\hline $1-G^{2}$ & 15 plano-axiais. & Contornos: & $10-15-20-25-30 \%$ \\
\hline $1-G^{\prime}$ & 20 eixos de dobras. & Contornos: & $10-20-30 \%$ \\
\hline $2-G^{2}$ & 25 plano-axiais. & Contornos: & $10-20-30 \%$ \\
\hline $1-H$ & 30 pólos. Foliação. & Contornos: & $3-5-7-9 \%$ \\
\hline $2-H$ & 40 pólos. Foliação. & Contornos: & $3-7-11-15 \%$ \\
\hline $3-H$ & 50 pólos. Foliação. & Contornos: & $2-14-28-42 \%$ \\
\hline $1-H^{\prime}$ & 20 eixos de dobras. & Contornos: & $3 \cdot 6 \%$ \\
\hline $2-H^{2}$ & 30 eixos de dobras. & Contornos: & $3-5-7-9 \%$ \\
\hline $1-1$ & 100 pólos. Foliação. & Contornos: & $1-4-10-16 \%$ \\
\hline $2-I$ & 40 pólos. Foliação. & Contornos: & $2-6-9-12-15 \%$ \\
\hline $3-I$ & 66 pólos. Foliação. & Contornos: & $4-8-12-16-20-24 \%$ \\
\hline $4-1$ & 37 pólos. Foliação. & Contornos: & $2-6-9-13 \%$ \\
\hline
\end{tabular}

Tabela 2 - Foliaçâo

\begin{tabular}{c|c|c|c}
\hline \multirow{2}{*}{ Máximo } & \multirow{2}{*}{ Direção } & \multicolumn{2}{|c}{ Diagramas } \\
\cline { 2 - 4 } & I & Complexo de Silvianópolis & Grupo Amparo \\
\hline II & N30-40W & $1,2,2-A, 2-B, 4-C$ e 3-D & $\begin{array}{l}3-A, 2-B, 2-C, \\
1-G, 2-D \text { e } 2-E\end{array}$ \\
\hline III & N60-80E & $4-C, 2-I$ e 1-H & $\begin{array}{l}2-F, 2-G, 2-H, \\
1-I, I-G \text { e 3-E }\end{array}$ \\
\hline
\end{tabular}


Tabela 3 - Eixos de dobras

\begin{tabular}{|c|c|c|c|}
\hline \multirow{2}{*}{ Máximo } & \multirow{2}{*}{ Direção } & \multicolumn{2}{|c|}{ Diagramas } \\
\hline & & Complexo de Silvianópolis & Grupo Amparo \\
\hline I & $\begin{array}{l}\text { N80-90E } \\
\text { N80-90W }\end{array}$ & $1-H^{I}$ & $\begin{array}{c}2 * F^{2}, 2-G^{\prime} \mathrm{e} \\
2-H^{\prime}\end{array}$ \\
\hline II & $\begin{array}{l}\mathrm{N} 30-40 \mathrm{E} \\
\mathrm{N} 30-40 \mathrm{~W}\end{array}$ & $1-H^{\prime}$ & $\begin{array}{c}1-G^{\prime}, 2-G^{\prime}, 2-F^{2} \\
2-E^{\prime} \text { e } 2-H^{\prime}\end{array}$ \\
\hline III & $\begin{array}{l}\text { N30-40W } \\
\text { N30-40E }\end{array}$ & - & $\begin{array}{c}1-G^{\prime}, 2-H^{I} \mathrm{e} \\
2-F^{2}\end{array}$ \\
\hline
\end{tabular}

Apenas dois diagramas caracterizam melhor a disposição espacial da foliação, mostrando estar dobrada, em dobras do tipo aberta, e com eixos $\beta$ inclinados para sudoeste e em direçåo NE-SW (diagramas $1-F$ e $3-I$ ). Nos demais casos, as concentraçōes de pólos não mostram tendência à distribuição em guirlanda. $\mathrm{Na}$ realidade, trata-se das mesmas dobras cujas concentrações de pólos são relacionadas ao máximo II. Neste caso, apresentam uma inflexão para NE, tendência esta também verificada à escala do mapeamento (ver mapa geologico-estrutural anexo).

A Tab. 3 mostra, à semelhança da Tab. 2, três máximos de concentração de atitudes de eixos de dobras. $O$ máximo I mostra eixos de dobras com rumos $\mathrm{N}$ 80-90 $\mathrm{E}$ e N 80-90 W, ocorrentes tanto no Grupo Amparo como no Complexo de Silvianópolis; o máximo II mostra eixos de dobras com rumos entre $N 30-40$ E e S 30-40 W; e o máximo III mostra eixos de dobras com rumos N 30-40 E e S 30-40 E. Comparando-se esses dados com os eixos $\beta$, calculados estatisticamente a partir de dados de foliação, observa-se uma perfeita concordância tanto no rumo dos eixos como também no plunge dos mesmos. Esses três máximos distintos de concentração de eixos de dobras sugerem a existência de dobramentos superpostos na área.

\section{ANÁLISE DAS UNIDADES LITOESTRUTURAIS}

\section{COMPLEXO DE SILVIANÓPOLIS Os diagramas} de pólos de superfícies $S$, exceção feita aos de números 1 e 2, na parte norte da área, referentes ao Complexo de Silvianópolis, não mostram um ponto máximo bem definido nem é possível traçar qualquer tipo de guirlanda completa, mostrando padrōes com simetria triclínica (Patterson e Weiss, 1961). Isso acontece quando tanto os flancos como a zona de charneira de dobras preexistentes sðo afetados por diversos dobramentos superpostos. A foliação (ou o acamamento sedimentar) originada em uma fase de dobramento anterior sofrerá uma row tação ao longo de cada eixo das dobras superpostas, ocasionando uma dispersão dos valores, traduzindo-se no diagrama por uma impossibilidade de se traçar qualquer guirlanda ao redor dos eixos dos últimos dobramentos.
A foliação nos diagramas de números $2-A, 3-B, 4-C$, $3-D$ e 3-E não apresenta distribuição em guirlanda nem um único máximo bem definido, de maneira que nenhum eixo $\beta$ pode ser determinado. Em alguns casos, como, por exemplo, os diagramas $3-E$ e $1-H$, a existência de dobras abertas é sugerida com eixo de direção nordeste e leste-oeste inclinado para nordeste (3-E) e para oeste $(1-H)$.

Nos diagramas 1 e 2 , no entanto, os efeitos da fase $F n+2$ são mais intensos, reorientando a foliação para noroeste. Diagramas desse tipo, mostrando um ponto máximo bem definido (ou simetria axial), são indicativos de uma série de planos estatisticamente paralelos. Este fato deve-se a uma zona de dobra, estatisticamente planar (flanco), ou a uma série de dobras isoclinais com áreas dominantes de flancos e com zonas de charneira de pequena extensão areal. A verificação no campo de dobras isoclinais e apertadas nessa área sugere que os máximos dos diagramas 1 e 2 são devido a uma série de flancos de dobras isoclinais em vez de um único flanco de.dobra.

No caso do diagrama $2-I$, situado na parte sul da área, a maior intensidade do dobramento $F n+3$ reorientou a foliação $S T$ para um valor próximo a lesteoeste.

Os diagramas de pólos de foliação $S T$, nas rochas do Complexo de Silvianópolis, indicam seguramente a existência de dois diferentes tipos de dobramentos, baseando-se em seus estilos e suas direçðes preferenciais denominados de fase $F n+3$ e $F n+2$. A primeira reorienta a foliação $S T$ para nordeste (diagramas 3-E, 1- $H$ e $2-I$ ) e a segunda, para noroeste (diagramas 1 e 2). Além disso, os diagramas $3-E, 1-H$ e $2-I$ sugerem a presença de dobras abertas e com superfícies axiais aproximadamente verticais, com eixos de direção nordeste e caimentos para nordeste e sudoeste enquanto os diagramas 1 e 2 indicam dobras isoclinais com superfícies axiais inclinadas para sudoeste e eixos orientados para noroeste, com caimentos para noroeste.

Indiretamente, os diagramas de pólos indicam a existência da fase de deformação $F n+1$, mais antiga, pois as dobras $F n+2$ são desenhadas pela foliação $S T$ (dobramento isoclinal da foliação $S T$ que, como já se viu, originou-se em posição plano-axial). 


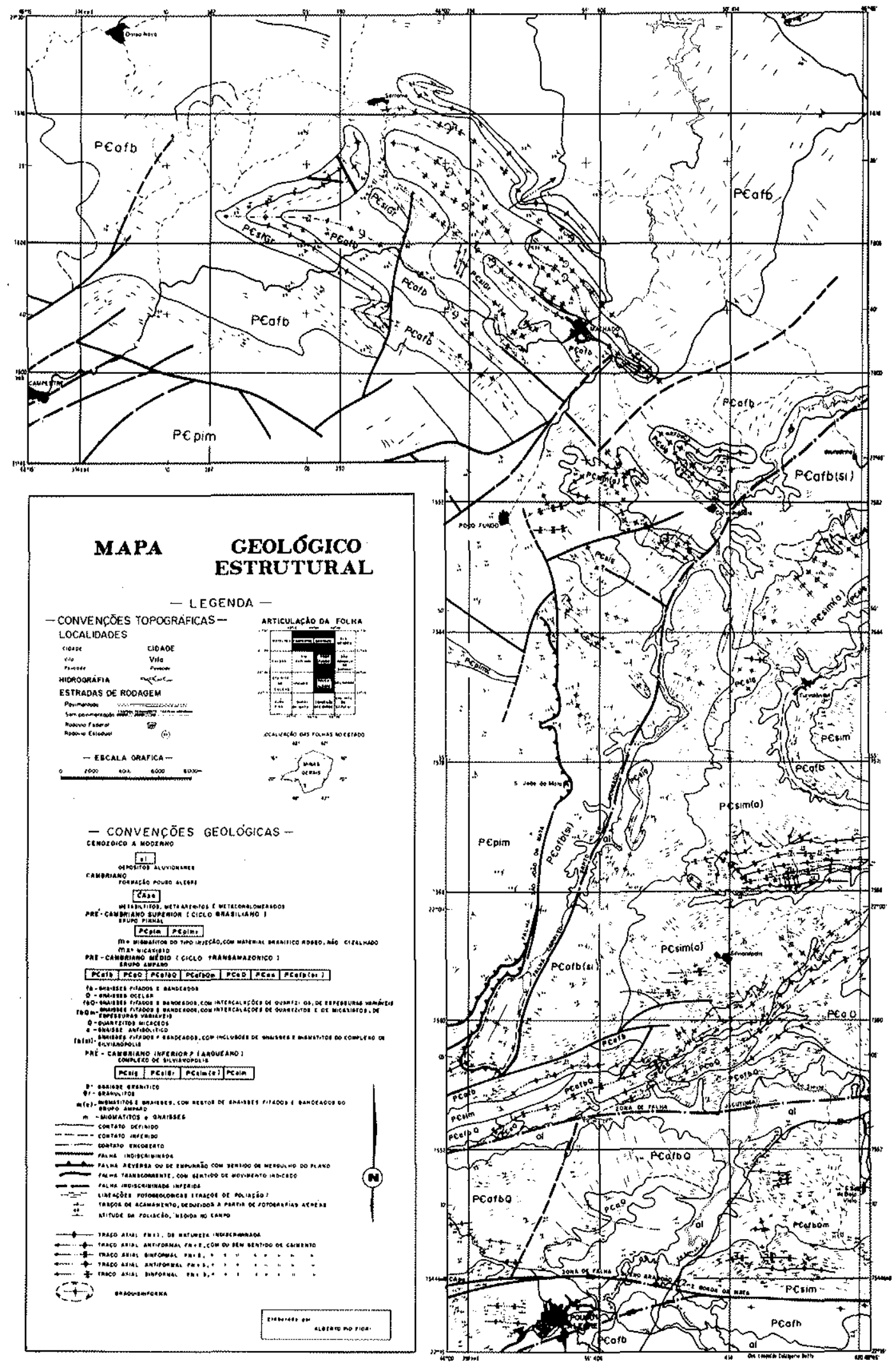

Figura 1 - Mapa geológico-estrutural da região de Pouso Alegre-Machado (MG) 


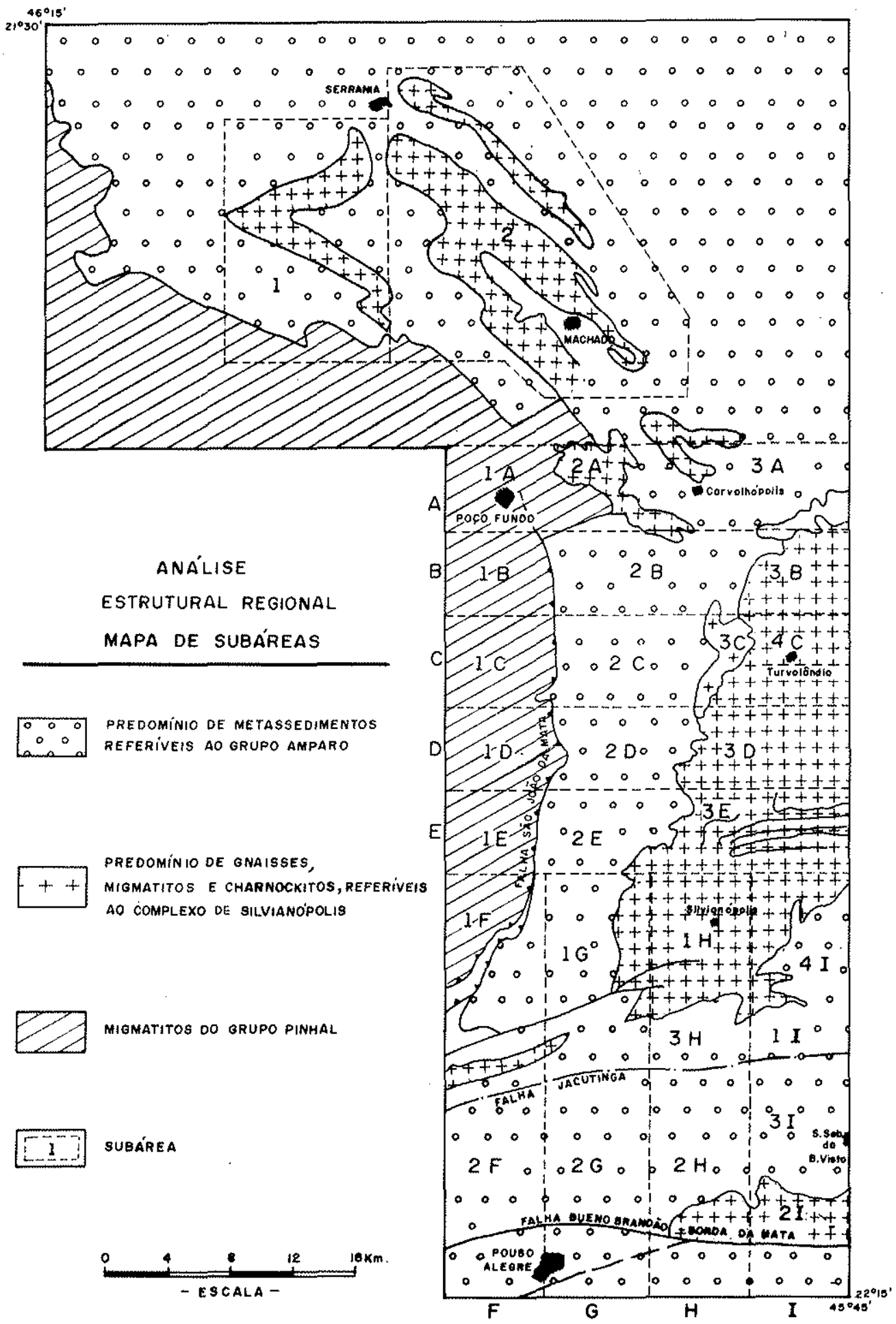

Figura $2-$ Análise estrutural regional 

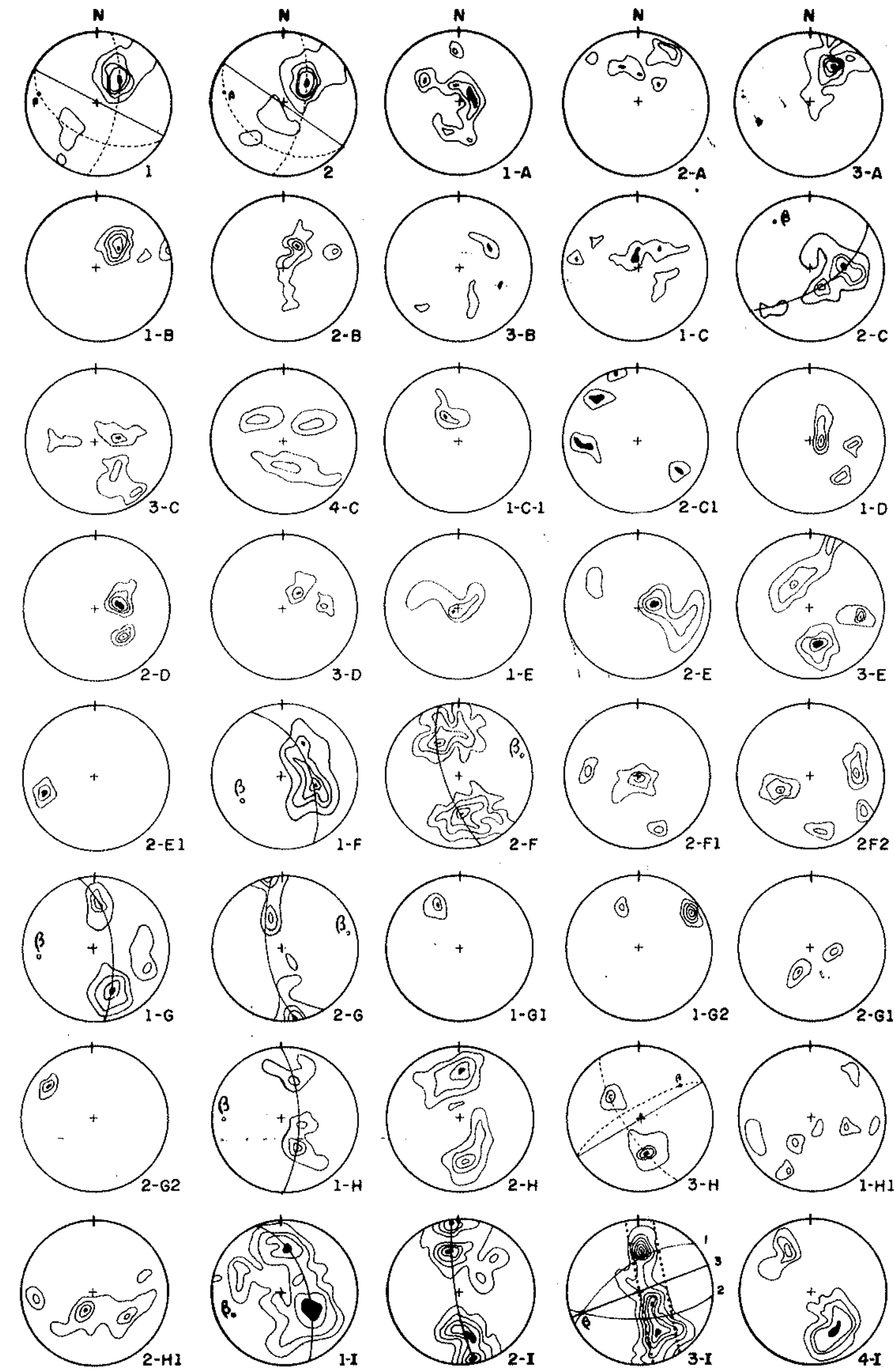

Figura 3 - Diagramas de pólos 
As dobras ocorrentes nos migmatitos e gnaisses do Complexo de Silvianópolis são de dimensões muito pequenas, em geral nåo excedendo a $5 \mathrm{~cm}$ de comprimento. Na grande maioria dos casos, na realidade, são dobras de dimensoes milimétricas representadas apenas por seus ápices (rootless fold). Por tal motivo, a obtencăo de dados dessas estruturas, especialmente no que se refere a orientaça de seus eixos, é tarefa bastante difícil, necessitando-se de outra metodologia como, por exemplo, a coleta de amostras orientadas e posterior análise microtectônica. No entanto, o diagrama 1. $H^{l}$ mostra o resultado obtido pelo lançamento de vinte eixos no diagrama circular e posterior contorno. Não se observa nenhum máximo, a exemplo do que se verificou com os dados planares. Na realidade, tal diagrama mostra a existência de dobras com eixos orientados para noroeste, nordeste e aproximadamente leste-oeste, deixando presumir a existência de superposição de fases de dobramento.

GRUPO AMPARO O tipo mais comum de diagrama de pólos de foliação $S T$, neste grupo, especialmente na parte sul da área, mostra uma guirlanda parcial ou completa, provando conclusivamente a presença de dobramento em escala regional, com o eixo da dobra sendo representado pelo pólo da guirlanda. Em um certo número de exemplos, no entanto, o diagrama de pólos deixa de mostrar uma guirlanda bem definida, sugerindo, em vez disso, uma dispersão de dados indicativa de superposição de deformação.

Nos casos em que o pólo de uma guirlanda bem definida pode ser reconhecido como o eixo de uma deformação superposta, deverá haver um ponto máximo antès da formação superposta; em caso contrário, a dispersão será maior com o diagrama tendendo à simetria triclínica. No caso de existir um máximo antes da deformação superposta, as dobras anteriores deverão ser isoclinais com os flancos estatisticamente paralelos. Uma dobra isoclinal preexistente, com os planos $S$ estatisticamente paralelos (planos 1 e 2, na Fig. 3.3-I, representando os dois máximos), afetada por um dobramento posterior de plano axial vertical (plano 3 ) deverá ser redobrada em torno de $\beta$. Desse redobramento resultará um espalhamento dos pólos, que deveråo situar-se dentro da zona demarcada pelos dois arcos pontilhados. A dobra superimposta é do tipo aberta e seu plano axial é, na realidade, um plano de simetria do diagrama de pólo.

Dessa forma, as guirlandas completas ou parciais, obtidas pelos pólos de foliação nas litologias do Grupo Amparo, na parte sul da área, mostram que as dobras isoclinais preexistentes foram redobradas por dobras abertas, do tipo flexural. As investigaçðes de campo mostram que as dobras isoclinais da primeira geração são, na realidade, da fase $F n+1$ e as dobras superimpostas, do tipo abertas, pertencem à fase $F n+3$ (para maiores detalhes, ver Fiori, 1979). As dobras $F n+2$ não são detectadas pelos diagramas de pólos de foliação, no entanto sua existência pode ser reconhecida no campo. $\mathrm{Na}$ realidade, a influência das dobras $F n+2$ diminui rapidamente ao sul da falha de Jacutinga, como pode ser verificado no mapa geológico-estrutural da área.

As medidas de atitudes de planos axiais foram efetuadas em dobras de dimensðes métricas restritas à área de ocorrência do Grupo Amparo. Os diagramas ilustrativos dos planos foram deduzidos a partir de quarenta medidas, talvez insuficientes para ser considerados representativos de toda a região mapeada. Este fato devese ao número relativamente pequeno de dobras para cada subárea, impossibilitando uma concentração maior de dados que pudessem ser lançados em diagrama. No entanto, dois máximos bem definidos foram obtidos: no diagrama $1-\mathrm{G}^{2}$, o máximo obtido é representativo de dobras da fase $F n+3$, com a superfície axial orientada para N $45 \mathrm{E}$; no diagrama $3.1-\mathrm{G}^{2}$, o máximo obtido demonstra a orientação de superfícies axiais orientadas para N $20 \mathrm{~W}$ representando as dobras da fase $F n+2$. Uma pequena concentração de pólos nesse último diagrama demonstra a ocorrência de um pequeno número de dobras $F n+3$, com atitude axial $\mathrm{N} 35 \mathrm{E}$. Os valores médios obtidos das superfícies axiais não só acompanham as direções gerais observáveis para a foliação das rochas como também apresentam coincidência de valores dos ângulos de mergulho para sudoeste, como é o caso do diagrama $3.1-\mathrm{G}^{2}$, indicando dobramento do tipo isoclinal da foliação.

Os eixos de dobras medidos nas rochas do Grupo Amparo foram obtidos geralmente em dobras de dimensठes métricas e mais raramente em dobras de dimensðes centimétricas. Conforme pode-se observar na Tab. 3, nesse grupo ocorrem eixos de dobras cujas orientaç̃es se situam nos máximos I, II e III. No caso do diagrama $2-F^{2}$, nota-se a ausência de eixos de dobras com rumo $\mathrm{N}-\mathrm{W}$. No entanto, a presença desses eixos está indicada nos diagramas $3.1-\mathrm{G}^{1}, 3.1-\mathrm{H}^{1}$ e $3.2-\mathrm{F}^{2}$, atestando a existência de dobras orientadas para noroeste na parte sul da área.

Assim, resumindo-se a fase de deformação $F n+1$ do Grupo Amparo é representada por dobras isoclinais com foliação de transposição do acamamento desenvolvida em posiçåo plano-axial. No Complexo de Sivianópolis, é também reconhecida como uma foliação de transposição originando dobras de cisalhamento, porém em estruturas migmatíticas preexistentes. A fase da deformação $F n+2$ é reconhecida no Complexo de Silvianópolis e nas rochas do Grupo Amparo. Está mais bem desenvolvida na parte norte da área, nas proximidades de Machado e Serrania. Os eixos e traços axiais dessas dobras têm direção dominantemente noroeste (N 40-50 W), infletindo-se na altura de Serrania para aproximadamente leste-oeste, provavelmente por influência do Maciço de Pinhal. No entanto, esse fenômeno é localizado retomando as estruturas novamente a direção noroeste, mais ao norte. Aparentemente, apresentam um decréscimo de intensidade de norte para sul. As dobras da fase $F n+3$ desenvolvem-se de uma maneira generalizada por toda a área estudada. No entanto são mais notáveis na parte sul da área. Săo dobras com eixos e traços axiais de direção nordeste com máximos $\mathrm{N}$ 30-40 E e N 80-90 E, bastante consistentes, pois não apresentam deformações superimpostas. São dobras da geração mais nova e afetam todas as rochas e as estruturas previamente formadas.

EVOLUÇÃO ESTRUTURAL As rochas mais antigas da área constituem um conjunto litológico, aqui de- 
nominado Complexo de Silvianópolis, cujos tipos litológicos que o constituem são migmatitos-gnaisses, granulitos e gnaisses graníticos. Os dois últimos tipos representam corpos mais ou menos isolados, de formas alongadas ou lenticulares, inclusos dentro do domínio maior migmatítico-gnáissico.

Os migmatitos do Complexo de Silvianópolišsão do tipo de segregação, gerados in situ e caracterizados por alternância de bandas claras e escuras, originando padrôes estruturais bastante diversos. Aș bandas claras são de composição essencialmente quartzo-feldspática e as escuras de biotita e hornblenda. São semelhantes aos migmatitos do Grupo Barbacena, de idade arqueana.

Essa fase de migmatização é anterior à sedimentação do Grupo Amparo, pois metassedimentos deste último, sem quaisquer evidência de anatexia, encontram-se em contato direto com migmatitos do Complexo de Silvianópolis. Além disso, ambos são estruturalmente diferentes como Grupo Amparo apresentando um menor número de deformações superimpostas. A esta fase de migmatização mais antiga detectada na área denominou-se Fn. Alguns dados de campo mostram que essa fase foi precedida por um dobramento isoclinal, mas mais estudos fazem-se necessários para uma melhor caracterização desse dobramento.

A seguir, advém um período de sedimentação predominantemente clasto-química, com épocas de atividade vulcânica gerando corpos ígneos concordantes (sills" e tufos). Toda a sequêencia resultante que constitui o Grupo Amparo foi depositada sobre as rochas do Complexo de Silvianópolis (Fig. 4a).

Após o período de sedimentação, advém a fase de dobramento $F n+1$. Esta fase caracterizou-se por dobramento isoclinal e, nas rochas do Grupo Amparo, as dobras $F n+1$ são configuradas pelo antigo acamamento sedimentar, ou superfície So, tendo-se desenvolvido uma intensa foliação em posição plano-axial denominada foliação $S T$. Em toda a área de ocorrência do Grupo Amparo, a foliação $S T$ é paralela à $S o$, tendo sido caracterizada como foliação de transposição (Fig. $4 b$ ).

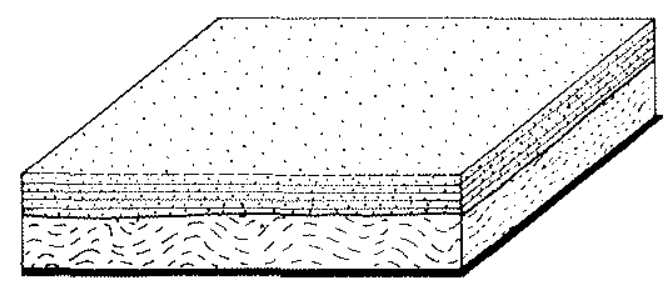

A - DEPOSICĀO OO GRUPO AMPARO

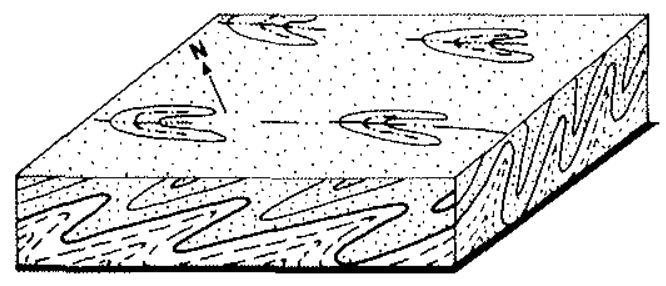

C - FASE DE DOBRAMENTO Fn+ 2

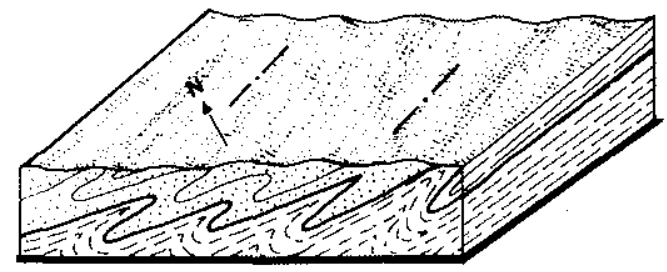

B - FASE DE DOBRAMENTO $\mathrm{F} n+1$

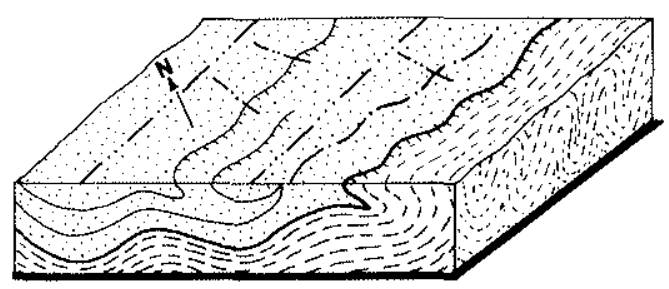

D - FASE DE DOBRAMENTOF +3 
O dobramento das rochas do Complexo de Silvianópolis deu-se por fenômenos de cisalhamento (dobras de cisalhamento) transpondo as estruturas migmatíticas originais e tornando estruturalmente concordantes as rochas desse complexo com as do Grupo Amparo, pela foliação $S T$. Como resultado final, as rochas com estruturas migmatíticas do complexo transformaram-se em gnaisses e os antigos sedimentos do Grupo Amparo, em gnaisses fitados e bandeados, com o bandeamento representando o antigo acamamento sedimentar paralelamente ao qual se desenvolveu a foliação $S T$.

No final dessa fase de dobramento isoclinal e transposição, segue-se, no tempo, uma fase de migmatização $M 2$ pouco intensa que, conforme dataçðes geocronológicas, estaria situada entre 18002000 m.a. Sua posição temporal relativa está bem assegurada ao afetar rochas do Grupo Amparo e recristalizar minerais esmagados ao longo das superfícies axiais de dobras $F n+1$ (foliação ST).

Os esforços principais atuantes durante a fase $F n+1$ devem ter tido direção aproximadamente de $\mathrm{N} 20 \mathrm{~W}$ a $\mathrm{N}-\mathrm{S}$, de caráter tangencial. É difícil reconstruir o exato quadro dinâmico dessa fase devido às modificações impostas posteriormente, mais, ao que tudo indica, a vergência do dobramento $F n+1$ é sul-sudeste deduzida a partir da geometria dos dobramentos superpostos. $\mathrm{O}$ fato de o dobramento $F n+1$ ter afetado tanto o embasamento como a cobertura, tornando-os estruturalmente concordantes (pela foliação $S T$ ), deu origem a inclusðes tectônicas de rochas do embasamento (Complexo de Silvianópolis) no Grupo Amparo. Essas inclusōes deveriam ter formas alongadas representando tanto antiformas como sinformas.

A seguir, no intervalo de tempo entre 1000 e 1300 m.a., a regiåo volta a sofrer nova fase de deformação. Os esforços atuantes têm direção nordeste-sudoeste e tiveram intensidade tal a ponto de dobrar isoclinalmente as rochas da área. No entanto não foi tão intensa como a fase anterior, devendo situar-se em intensidade entre as dobras do tipo 2 e 3 de Ramsay (1967), ou seja, no início da fase de deformação plástica (ou flattening). Esta fase é seguramente posterior à fase $F n+1$, pois redobra as dobras geradas na fase anterior e dobra a foliação $S T$. Sua inclusão no Ciclo Uruaçuano é feita tentativamente, pois as direções uruaçuanas são noroeste $\mathrm{e}$ apresentam continuidade física com as superfícies axiais das dobras $F n+2$ da área estudada. Além disso, são afetadas por dobras $F n+3$ anteriores à fase de migmatização Brasiliana. A esta fase não se associam fenômenos de migmatização ou anatexia.

O redobramento de dobras geradas na fase de deformação $F n+1$ por dobras $F n+2$ dá origem a estruturas de redobramento cuja figura bidimensional, no corte topográfico atual, origina figuras de interferência do tipo 2 de Ramsay; ou seja, com forma de crescente (Fig. 4c). Esse tipo de figura de interferência é obtida ao se redobrarem isoclinalmente dobras isoclinais deitadas ou inclinadas com os eixos de ambas as séries de dobras dispostas transversalmente. A vergência das dobras $F n+2$ é nitidamente para norte-nordeste, com suas superfícies axiais inclinadas para sudoeste com valores entre $40^{\circ} \mathrm{e}$ $50^{\circ}$.
Finalmente, segue-se a fase de dobramento $F n+3$, de direção axial nordeste, sem vergência definida, e esforços atuantes segundo a direção noroeste-sudeste. É a fase mais recente identificada na área e também a que afetou de forma mais suave as rochas da região. São dobras abertas, do tipo concêntricas, geradas por processo flexural, sem desenvolvimento de foliação plano-axial. Săo as responsáveis pelo padrão morfo-estrutural identificado principalmente na faixa metassedimentar de Ouro Fino-Pouso Alegre. No tempo, situam-se um pouco antes do fenômeno de migmatização do Grupo Pinhal, de idade Brasiliana (de 550 a 600 m.a.), pois são truncadas pelo Maciço de Pinhal. Sua idade está assim situada entre 1000 m.a. e $600 \mathrm{~m}$.a., pois também são posteriores à fase de dobramento $F n+2$.

De aparência bastante simples no mapa, as dobras $F n+3$, na realidade, dão origem a estruturas complexas: redobram as dobras $F n+1$ (e a foliação $S T$ ) de forma aproximadamente co-axial e as dobras $F n+2$, de forma transversal. Essas dobras provavelmente correspondem às dobras $F 2$ de Hasui (1973); às dobras $F 2$ de Sadowski (1974); e às dobras D2 de Carneiro (1977) (Fig. 4d).

A superposição de dobras $F n+3$ sobre as dobras $F n+1$ deu origem a figuras de interferência do tipo 3 de Ramsay.

A história evolutiva acima representada acha-se resumida na Tab. 4.

CONCLUSŌes 1. A geologia da área é composta por três grandes conjuntos litológicos distintos, de idade pré-cambriana: o Grupo Pinhal, de idade brasiliana; o Grupo Amparo, de idade transamazônica; e o Complexo de Silvianópolis, de idade arqueana. Subsidiariamente, ocorre a Formação Pouso Alegre, representada por uma pequena mancha isolada e faixas mais extensas, aluviais, situadas ao longo dos maiores escoradouros da área.

2. O Grupo Pinhal é representado por migmatitos de injeção com o neossoma de composição granítica de cor rósea. O Grupo Amparo é representado essencialmente por metassedimentos que foram subdivididos em sete associaçð̄es diferentes, e o Complexo de Silvianópolis, por migmatitos, gnaisses e granulitos, sendo também subdividido em três diferentes associaçôes litológicas. A Formação Pouso Alegre é representada por metassedimentos pouco metamórficos e as aluvióes por sedimentos areno-argilosos.

3. A diferença fundamental entre o Grupo Amparo e o Complexo de Silvianópolis é em base estrutural, com o último evidenciando um estilo de deformação mais complexo que o primeiro. O Complexo de Silvianópolis representa o embasamento do Grupo Amparo.

4. A análise estrutural revelou que a área sofreu uma evolução policíclica, tendo sido reconhecidas as fases de deformação $F n, F n+1, F n+2$ e $F n+3$, da mais antiga para a mais recente.

5. A fase Fn representa o resultado final de uma migmatização arqueana relacionada ao Ciclo Barbacena. $\hat{\mathrm{E}}$ reconhecida só nas rochas do Complexo de Silvianópolis. 
Tabela 4 -

\begin{tabular}{|c|c|c|c|c|c|}
\hline Ciclo & $\begin{array}{l}\text { Fase de } \\
\text { formação }\end{array}$ & $\begin{array}{c}\text { Tipos } \\
\text { litológicos } \\
\text { principais }\end{array}$ & $\begin{array}{c}\text { Características } \\
\text { estruturais } \\
\text { principais }\end{array}$ & $\begin{array}{l}\text { Efeitos das } \\
\text { superposiçōes } \\
\text { de fases }\end{array}$ & $\begin{array}{c}\text { Prováveis } \\
\text { intervalos } \\
\text { de idades } \\
\text { de fases } \\
\text { de deformação }\end{array}$ \\
\hline Brasiliano & $F n+3$ & $\begin{array}{l}\text { Grupo Pinhal: Mig- } \\
\text { matitos do tipo de in- } \\
\text { jeçăo }\end{array}$ & $\begin{array}{l}\text { Dobramento flexural da } \\
\text { foliação } S T \text { seguida da } \\
\text { migmatização do Grupo } \\
\text { Pinhal. Dobras abertas } \\
\text { orientadas para NE }\end{array}$ & $\begin{array}{l}F n+3 / F n+1=\text { figuras } \\
\text { de interferência do tipo } 3 \\
\text { de Ramsay. } \\
F n+3 / F n+2=\text { não ca- } \\
\text { racterizada na área. } \\
\text { Obs.: Arqueamento das } \\
\text { figuras de interferência } \\
\text { do tipo } 2 \text { de Ramsay. }\end{array}$ & 650-1 000 m.a. \\
\hline Uruaçuano & $F n+2$ & $\begin{array}{l}\text { Năo ocorrem tipos li- } \\
\text { tologicos referiveis a } \\
\text { este ciclo }\end{array}$ & $\begin{array}{l}\text { Dobramento isoclinal da } \\
\text { foliação } S T \text {. } \\
\text { Reorientação da fo- } \\
\text { liação } S T \text { para NW. } \\
\text { Aparentemente não de- } \\
\text { senvolveu foliação pla- } \\
\text { no-axial. }\end{array}$ & $\begin{array}{l}F n+2 / F n+1=\text { figuras } \\
\text { de interferência do tipo } 2 \\
\text { de Ramsay }\end{array}$ & $\begin{array}{l}1100-1400 \\
\text { m.a. }\end{array}$ \\
\hline Transamazônico & $F n+1$ & $\begin{array}{l}\text { Grupo Amparo: me- } \\
\text { tassedimentos com } \\
\text { estrutura fitada-ban- } \\
\text { deada }\end{array}$ & $\begin{array}{l}\text { Dobramento isoclinal do } \\
\text { acamamento sedimentar } \\
\text { seguido de transfor- } \\
\text { mação plano-axial. Ge- } \\
\text { ração da foliação } S T \text {. } \\
\text { Migmatização do Grupo } \\
\text { Amparo }\end{array}$ & $\begin{array}{l}F n+1 / F n=\text { dobras de } \\
\text { cisalhamento das estru- } \\
\text { turas migmatíticas. For- } \\
\text { mação de dobras intra- } \\
\text { foliares sem raiz (roo- } \\
\text { less fold) }\end{array}$ & $\begin{array}{l}1800-2000 \\
\text { m.a. }\end{array}$ \\
\hline Arqueano & $F n$ & $\begin{array}{l}\text { Complexo de Sil- } \\
\text { vianópolis: migmati- } \\
\text { tos, gnaisses e granu- } \\
\text { litos }\end{array}$ & $\begin{array}{l}\text { Migmatitos cinza, de se- } \\
\text { gregação }\end{array}$ & - & $?-2800$ m.a. \\
\hline
\end{tabular}

6. A fase $F n+1$ representa uma fase de dobramento isoclinal com transposição em posição plano-axial. Afeta tanto as litologias do Grupo Amparo como as litologias do Complexo de Silvianópolis. As dobras da fase $F_{n}+1$ são do tipo similares, com forte espessamento nos ápices e adelgaçamento nos flancos, freqüentemente podem ser reconhecidas como dobras intrafoliares disruptas. Pela foliação de transposição gerada nesta fase, as litologias do Grupo Amparo e a do Complexo de Silvianópolis tornaram-se estruturalmente concordantes. Foi relacionada ao Ciclo Transamazônico.

7. A fase de dobramento $F n+2$ representa o redobramento isoclinal das rochas do Grupo Amparo e do Complexo de Silvianópolis. Seus eixos e suas superfícies axiais têm direções dominantes para noroeste. São facilmente reconhecidas no campo ao dobrar a foliação de transposição gerada na fase $F n+1$. Năo deu origem a uma nova foliação plano-axial a não ser localmente. Foi tentativamente relacionada ao Ciclo Uruaçuano.

8. A fase $F n+3$ representa o redobramento de caráter flexural das rochas do Grupo Amparo e do
Complexo de Silvianópolis. Seus eixos e suas superfícies axiais têm direçōes dominantes nordeste com eixos apresentando caimentos tanto para nordeste como para sudoeste. Não apresentam vergência definida. Foi tentativamente relacionada ao Ciclo Brasiliano.

9. A superposição de dobramentos deu origem a estruturas de interferência bastante complexos. Figuras de interferência do tipo 2 e 3 puderam ser mapeados à escala 1:50 000, com o tipo 2 ocorrendo de preferência na parte norte da área e o segundo, na parte sul.

Agradecimentos Os autores desejam expressar os mais sinceros agradecimentos à Fundação de Amparo à Pesquisa do Estado de São Paulo (FAPESP) pelo auxílio financeiro (Processo 78/0213). Aos formandos do curso de Geologia de Rio Claro, turma de 1977, e aos professores que participaram do Projeto Pouso Alegre (Convênio DNPM/Unesp, Rio Claro), são apresentados idênticos agradecimentos. 


\section{BIBLIOGRAFIA}

ALMEIDA, F. F. M. de, HASUI, Y e NEVES, B. B, B, - -1976 - The upper precambrian of South America. Bol. I.G./USP, 7: 45-80.

CARNEIRO, C. D. R. - 1977 - Evoluçăo Geológica da Regiåo de Săo José dos Campos (SP). Atas do I Simp. Geol. Reg, (Soc. Bras. Geol. Núcleo de Sto Paulo), pp. 91-111.

CORDANI, U. G. e BITTENCOURT, 1. - 1967 - Determinaçăo de idade potássio-argônico em rochas do Grupo Açungui. An. XXI Congr. Bras. Geol., Curitiba, pp. 218-233.

CORDANI, U. G., DEL.HAL, J. e LEDENT, D. - 1973 - Orogeneses superpostes dans le précambrian du Brésil Sud-Oriental (Etat de Rio de Janeiro et de Minas Gerais). Rev. Bras, Geoc, 1 (3): 1-22.

CHOUDHURI, A., EBERT, H. e WINTERS, A. A. M. - 1978-Os metassedimentos e paragnaisses da regiáo Norte de Pouso Alegre, Sul de Minas Gerais. An. $X X X$ Congr. Bras. Geol., Recife, 1: 69-82,

CHOUDHURI, A., FIORI, A. P. e BETTENCOURT, J, S. - 1978 - Charnockitic Gneisses and Granulites of the Botelhos region, Southern Minas Gerais. An. XXX Congr. Bras. Geol, Recife, 1: 1236-1249.

CHOUDHURI, A., FIORI, A. P., WINTERS, A. A. M., BETTENCOURT, I. S. e RODRIGUES, J. E. - 1978 - A note on small bodies of eclogite as inclusiones in high grade gneisses, North of Pouso Alegre (MG). Rev. Bras. Geoc. 8 (1): 63-68.

EBERT, H. - 1956 - Beitrag zur Gliederung des Prakambriuns in Minas Gerais. Geol. Rundschat 45 (3): $471-521$.

EBERT, H. - 1968 - Ocorrência de fácies granuliticas no Sul de Minas Gerais e em áreas adjacentes, em dependência da Estrutura Orogênica: hipóteses sobre sua origem. An. Acad. Bras. Cien. 40: 215-229.

EBERT, H. e BROCHINl, M. F. - 1968 - Estudos Estratigráficos e Geocronológicos no Escudo Cristalino Brasileiro. Ciência e Cultura 20: 621-625.

EBERT, H. - 1971 - Ós paraibides entre Săo Joăo Del Rei (MG) e ltapira (SP) e a bifurcaçăo entre Parajbides e Araxaides (lnédito), $36 \mathrm{pp}$.

EBERT, H. - 1971 - Os paraibides entre Săo Joðo Del Rei (MG) e Itapira (SP) e a bifurcaçăo entre Paraibides e Araxaides. Soc. Bras. Geol. (Núcleo de Săo Paulo). Bol, Esp. (Resumo das Comunicaçðes do XXV Congr. Bras. Geol.) (1): $177-178$.

EBERT, H. - 1974 - O Grupo Eleutério e a Falha de Jacutinga (Nordeste de Săo Paulo), Soc. Bras. Geol. (Núcleo Rio Grande do Sul). Bol. Esp. (Resumo das Comunicaçðes do XXVIll Congr. Bras. Geol.) (1): 726-730.

FIORI, A. P., WERNICK, E. e BETTENCOURT, J. S. - 1978 - Evoluça policíclica na região nordeste do Estado de São Paulo e áreas vizinhas no Estado de Minas Gerais. An. XXX Congr. Bras. Geol., Recife, 1: 309-318.

FIORI, A. P, e CHOUDHURI, A. - 1979 - Fases de migmatizaçăo e dobramentos superpostos nas rochas granulíticas e nos migmatitos de Serrania e Machado (MG). Atas do $29^{\circ}$ Simp. Reg. Geol., Rio Claro, 1: 47-58.

HAMA, M. e CUNHA, H. C. S. - 1977 - Consideraç̋̃es sobre a idade radiométrica da Formaça Pouso Alegre e dos granitos pos-cambrianos da regita Sul do Estado de Minas Gerais e Nordeste do Estado de Sto Paulo. Atas do 1? Simp. Geol. Reg. (Soc. Bras. Geol., Núcleo de Sáo Paulo), pp. 48-58.
HASUI, Y. - 1973 - Tectônica da área das folhas de Săo Roque e Pilar do Sul. Tese de livre-docência. 1.G./USP (inédita), $190 \mathrm{pp}$

MEHNERT, K. R. - 1968 - Migmatites and the origin of granitic rocks. Elsevier Publ. Co., New York, 325 pp.

OLIVEIRA, M. A. F. - 1973 - Petrologia das rochas metamórficas da regito de Săo José do Rio Pardo (SP). Rev. Bras. Geoc. 3 (2): 257-278.

OLIVEIRA, M. A. F. de, e ALVES, F, R. - 1974 - Geologia e Petrografia da região de Caconde (SP). Anais do XXVIII Congr. Bras. Geol., Porto Alegre, 5: 133-143.

PIRES, F. R. M., LEONARDOS JR., O. H. e PARENTI COUTO, J, G. 1970 - Gonditos na regiăo de Pouso Alegre (MG). Min. e Met. 52 (312): 237-239.

PROJETO CAL.DAS $1-1974-$ - Coordenador: Vicente José Fúlfaro. Convênio DNPM-FFCL Rio Claro, Geologia, 22 pp.

PROJETO CALDAS II - $1975-$ Coordenador: Paulo César Soares Convênio DNPM-FFCL. Rio Claro, Geologia, 46 pp.

PROJETO OURO FINO - 1976 - Coordenador: Eberhard Wernick. Convênio DNPM-FFCL Rio Claro, Geologia, $97 \mathrm{pp}$.

PROJETO POUSO ALEGRE - 1977 - Coordenador; Jorge Silva Bettencourt. Convênio DNPM-FFCl Rio Claro, Geologia, $57 \mathrm{pp}$.

RAMSAY, J. G. - 1962 - Interference patterns produced by the superposition of folds of similar types. Journal of Geology 70 (4): 466-481.

RAMSAY, J. G. - 1967 - Folding and fracturing of rocks. McGraw-Hill Book Co. Inc., New York, 568 pp.

SADOWSKY, G. R. - 1974 - Tectônica da Serra de Cubalåo (SP). Tese de doutoramento, 1,G./USP (inédita), $159 \mathrm{pp}$.

WERNICK, E. - 1967 - A geologia da regiāo de Amparo (Leste do Estado de São Paulo). Unesp-Rio Claro, tese, $235 \mathrm{pp}$.

WERNICK, E. - 1972 - A Geologia do Maciço Granitico de Morungaba, Leste do Estado de Såo Paulo. Escola de Engenharia de Săo Carlos, Boletim de Geologia 16, $110 \mathrm{pp}$.

WERNICK, E. E FERNANDES, N. A. - 1972 - Triclinicidade de feldspatos potássicos de rochas graníticas do Maciço de Morungaba (SP). Anais XXVI Congr. Bras. Geol., Belém, 1: $51-56$.

WERNICK, E. e PENALVA, F, $-1973-$ As relaçðes entre os grupos Amparo e Itapira (SP). Soc. Bras. Geol. (Núcleo da Bahia), Bol. Esp. (Resumo das Comunicaçoes do XXVIII Congr. Bras. Geol.), (1): 116-117.

WERNICK, E., OLIVEIRA, M. A. F, de, KAWASHITA, K., CORDANI, U. G. e DELHAL J. - 1976 - Estudo geocronológico pelo método $\mathrm{Rb} / \mathrm{Sr}$ em rochas do bloco Jundiai e regioes adjacentes. Rev. Bras. Geoc. 1 (6): 125-135.

WERNICK, E. - 1978(a) - Contribuição à geologia do maciço de Guaxupé (SP e MG). Anais Acad. Bras. Ciên. 50 (3): 337-352.

WERNICK, E. - 1978(b) - O Grupo Pinhal na regiăo nordeste do Estado de Sao Paulo e áreas vizinhas do Estado de Minas Gerais (no prelo).

Recebido em 30 de outubro de 1980. 